\title{
MAGNETIC SIGNATURE OF THE SACO DO MAMANGUÁ AND PARATY-MIRIM COVE, RIO DE JANEIRO, BRAZIL
}

\author{
Janaina Anjos Melo and Yara Regina Marangoni
}

\begin{abstract}
In this work, we investigate the $\mathrm{N} 40^{\circ}-50^{\circ} \mathrm{E}$-oriented magnetic lineaments observed in the marine and aeromagnetic data from the Paraty-Mirim and Saco do Mamanguá (RJ) coves. The main characteristic of these lineaments is the presence of normal and reverse magnetic polarity, indicating that the bodies responsible for the anomalies may be of different ages or have suffered remagnetization effects by metamorphism or have distinct lithologies. The interpretative model of the anomalies was obtained by the 3D Magnetization Vector Inversion (MVI) and by the study of the geology and tectonics of the area. Our results suggest, as a more likely hypothesis, that the magnetic lineaments can be correlated with two tholeiitic dykes swarms, Resende-Ilha Grande and Serra do Mar, which have intruded the region at different times. The age formation of those swarms can be placed at time intervals where the Earth's magnetic field has normal and reverse polarities. The contrasts of magnetic susceptibility obtained from the models are consistent with contrasts of the lithology of basic dykes intruded in the gneissic-granitic basement of the region.
\end{abstract}

Keywords: magnetization vector inversion, magnetic properties, magnetic lineaments, remanent magnetization, tholeiitic dykes swarms.

RESUMO. Neste trabalho, investigamos os lineamentos magnéticos orientados a $\mathrm{N} 40^{\circ}-50^{\circ} \mathrm{E}$ observados nos dados marinhos e aeromagnéticos das enseadas de Paraty-Mirim e do Saco do Mamanguá (RJ). A principal característica destes lineamentos é a presença de polaridade magnética normal e reversa, indicando que os corpos responsáveis pelas anomalias podem ter idades diferentes ou terem sofrido efeitos de remagnetização por metamorfismo ou apresentarem litologias distintas. O modelo interpretativo das anomalias foi obtido pela Inversão do Vetor de Magnetização (IVM) 3D e pelo estudo da geologia e tectônica da área. Nossos resultados sugerem, como hipótese mais provável, que os lineamentos magnéticos podem ser correlacionados com dois enxames de diques toleíticos, Resende-Ilha Grande e Serra do Mar, que têm idades diferentes de intrusão. As idades de formação desses enxames podem ser colocadas em intervalos de tempo em que o campo magnético da Terra apresentou polaridades normal e reversa. Os contrastes de susceptibilidade magnética obtidos no modelo são coerentes com os contrastes de litologia de diques básicos intrudidos no embasamento granítico-gnáissico da região.

Palavras-chave: inversão do vetor de magnetização, propriedades magnéticas, lineamentos magnéticos, magnetização remanente, enxames de diques toleíticos. 


\section{INTRODUCTION}

Recent researches conducted in the region of the Saco do Mamanguá and in the Cove of Paraty-Mirim reported the occurrence of gas in shallow sediments of the Holocene or Pleistocene period throughout the area, with a greater gas concentration in the inner portion of the estuaries (Benites et al., 2015; Maly, 2017). Studying the role of magnetostatic bacteria in the methane gas production and sediment composition of the Saco do Mamanguá, Rodelli et al. (2019) reported the presence of biogenic magnetite mixed with small concentrations of hematite and detrital magnetite from locally weathered granites. Pedogenic processes covering soil erosion and deposition of soil particles also contribute to the production of these magnetic minerals in the estuarine environment (Rodelli et al. 2019).

The Mamanguá Project executed in 2017 covers the magnetic research carried out at Saco do Mamanguá and Paraty-Mirim Cove and is part of a larger project to study in detail some features of the coast of São Paulo and Rio de Janeiro states. The magnetic study in the area reveals NE-SW magnetic lineaments of distinct polarities associated with different magnetization properties. They can be indicative of fault zones, variations in geological contacts or associated with intrusive features possible intruding at different times, with normal and reverse geomagnetic field polarity.

The geological and geophysical interpretation of these structures can help to understand the tectonic and evolutionary processes that worked along the Brazilian coast. In this way, the present paper aims to estimate the direction and amplitude of the total magnetization vector and the average magnetic susceptibility of marine geological structures, providing an interpretative geological model for the investigated area. We will apply the 3D Magnetization Vector Inversion (MVI) technique to marine and airborne data to accomplish our objective.

\section{STUDY AREA}

Saco do Mamanguá and Paraty-Mirim Cove are located in the county of Paraty, on the southern coast of the state of Rio de Janeiro (Fig. 1A). These rias (i.e. ancient river valley flooded by rising sea level during a transgressive event of the Holocene (Castaing \& Guilcher, 1995)) of low energy sedimentary conditions
(Benites et al., 2015; Maly, 2017) are adjacent and situated at the southwest end of the Bay of llha Grande (Fig. 1B), characterized by the presence of several islands composed by Precambrian granitic rocks (Suguio \& Martin, 1978).

Paraty-Mirim Ria (PMR) is a narrow E-W feature with dendritic morphology (Maly, 2017). Mamanguá Ria (MR) is inserted in the Mata Atlântica Forest domain as a narrow and elongated SW-NE feature, approximately $2 \mathrm{~km}$ wide and $11 \mathrm{~km}$ long (Benites et al., 2015; Maly, 2017; Rodelli et al., 2019; Brandini et al., 2019). MR and PMR present water depths of circa 6 and $8 \mathrm{~m}$ in their internal portion, respectively (Fig. 2). The outer portion of the MR presents a maximum depth of about $20 \mathrm{~m}$ (Fig. 2) (Benites et al., 2015; Brandini et al., 2019). According to Silvestre (2016), the relief of the region surrounding the rias is characterized predominantly by hills and relatively steep mountains (Rodelli et al., 2019) associated with continental, marine and mixed depositional areas. The hills and mountains have a gneissic and granitic basement that gives rise to residual, altered and slippery soils (Silvestre, 2016).

The study area is within the tectono-magmatic domain, Serra do Mar, characterized by the presence of orogenic granitoids, post-tectonic plutons and succession of magmatic arcs (Silva \& Cunha, 2001). This region is characterized essentially by a system of fractures and orthogonal faults in the SE-NW and SWNE directions that influence the disposition of geomorphological features (Benites et al., 2015; Rodelli et al., 2019). Rodelli et al. (2019) inferred that the granitic rocks present in the MR margin are associated with the Araçuaí orogenesis (Soares et al., 2007). The NE margin of the MR is predominantly composed of peraluminous granites and its SW margin is dominated by alkaline granites and gneisses leucogranites (Rodelli et al., 2019). Dantas (2000) stated that MR may have originated from the subsidence of blocks due to weak zones in the basement.

The immersed lands surrounding the rias are formed by Precambrian granites and migmatites (Benites et al., 2015; Maly, 2017). The geological framework of these adjacent terrains comprises the lithostratigraphic units: Parati Granite, Getulândia Suite, Rio Negro, Parati-Mirim Granite and Serra das Araras Suite (Fig. 1). In Serra das Araras Suite and Getulândia Suite it is found bodies with batholithic expression 

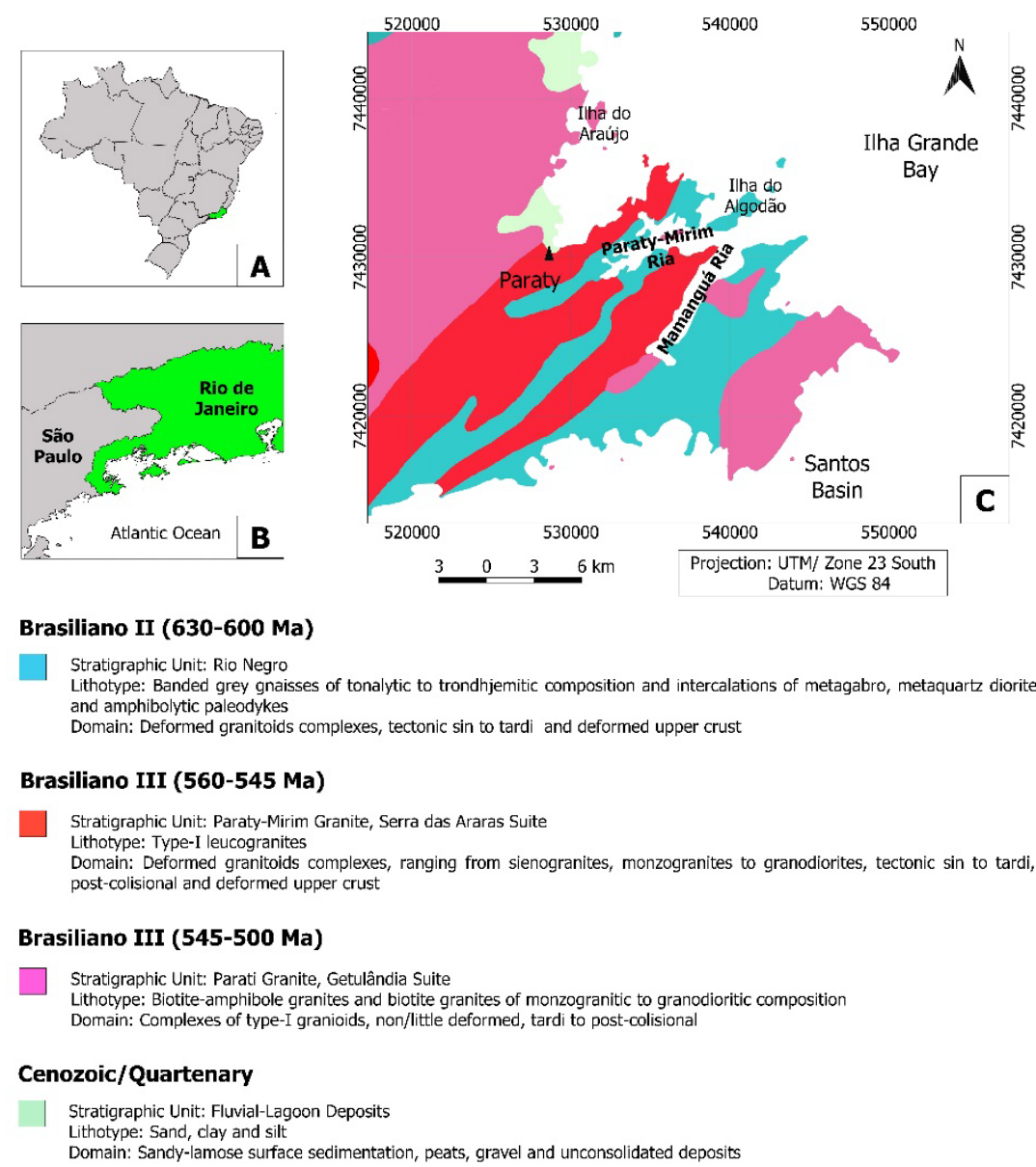

Stratigraphic Unit: Parati Granite, Getulândia Suite

Lithotype: Biotite-amphibole granites and biotite granites of monzogranitic to granodioritic composition Domain: Complexes of type-I granioids, non/little deformed, tardi to post-colisional

\section{Cenozoic/Quartenary}

| Stratigraphic Unit: Fluvial-Lagoon Deposits

Lithotype: Sand, clay and silt

Domain: Sandy-lamose surface sedimentation, peats, gravel and unconsolidated deposits

Figure 1 - Location of the study area (black polygon) in South America (A) and on the southern coast of Rio de Janeiro State (B). The geological map of area $(C)$ is modified from the OneGeology site. Shapefiles $(A)$ and $(B)$ are from the Brazilian Institute of Geography and Statistics (IBGE). Geological information is based on Maly (2017) and Silva \& Cunha (2001).

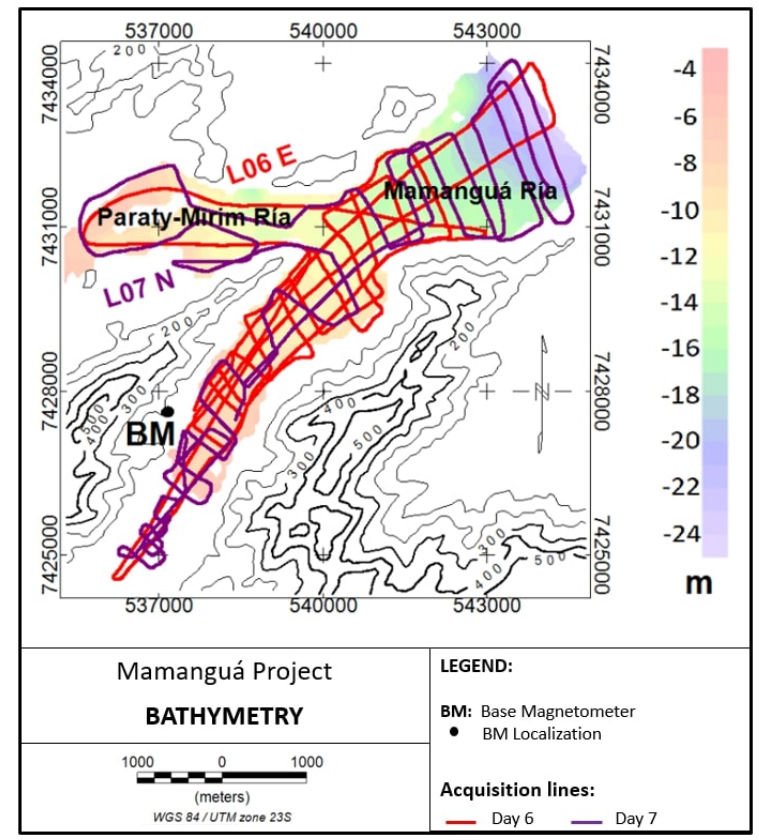

Figure 2 - Topographic map of the area with bathymetry (colored region) of the Mamanguá and Paraty-Mirim Rias and relief of the emerged environment (black level curves in meters). The location of acquisition lines from October 6th (red line) and 7th (purple line) and of the base magnetometer (BM) (black point) are highlighted. Bathymetric data is from Rodelli et al. (2019). 
(Silva \& Cunha, 2001). Igneous flow structures are common in the center of the batholith, and deformational structures predominate on the edge. These deformational structures resulted from NE-SW transcurrent shear (Silva \& Cunha, 2001). Almeida \& Carneiro (1998) stated that the diversity of lithotypes exhibited comes from a geological history between the Precambrian and the Eopaleozoic (Fig. 1). Also, these authors reported that the earliest dates from the coastal basement range from the Archean to the Lower Proterozoic. According to the literature (Telford et al., 1990; Blakely, 1996), these igneous and metamorphic terrains are expected to present high magnetic susceptibility values.

\section{DATABASE}

This study uses marine and aeromagnetic data (Melo et al., 2019). Marine magnetic data were collected by the boat of the Oceanographic Institute, University of São Paulo, on October 6th and 7th, 2017. Aeromagnetic data is from the Brazilian Geological Service (CPRM) and National Department of Mineral Production (DNPM) survey conducted from October 19th, 2010, to October 11th, 2013.

For marine data, a total of 43,451 measurements were done by covering about $150 \mathrm{~km}$ of profiles in the rias. As the estuarine environments are in the coastal region, it was possible to use a magnetometer as a base for recording the diurnal variation of the magnetic field. The GSM-19 Overhauser magnetometer used as base magnetometer has a resolution of $0.01 \mathrm{nT}$ and \pm $0.1 \mathrm{nT}$ of accuracy. It made a measurement every $30 \mathrm{~s}$ and was located in an area free of magnetic noise at the coordinate 537,153 UTMX, 7,427,670 UTMY (WGS84; Fig. 2), near Mamanguá Beach Hostel. The operation of a base magnetometer in a marine survey is a rare practice. Usually, marine surveys are carried out far from the coast and an ocean base station presents complex logistics and high cost (Plets et al., 2013).

A catamaran served as support for the SeaSpy Overhauser magnetometer, with $0.001 \mathrm{nT}$ resolution and $\pm 0.1 \mathrm{nT}$ accuracy. The distance between this magnetic sensor (fish) and the boat was 40 meters. The boat moved at an average speed of 8.9 knots (equivalent to $16 \mathrm{~km} / \mathrm{h}$ ). The sampling rate was $1 \mathrm{~Hz}$ for the fish, providing a measurement every $4.4 \mathrm{~m}$ on average. The height of the survey relative to the sea level was 0 meter.
Garmin 18x LVC GPS with high sensitivity was used for geographic coordinate data. As shown in Figure 2, the arrangement of the survey lines was irregular. Lines distance varied around 300 to $400 \mathrm{~m}$, except in some regions where they are closer. The average spacing of $350 \mathrm{~m}$ is adopted as the distance among the lines for mapping purposes. The magnetic inclination and declination were $-39.2^{\circ}$ and $-22.2^{\circ}$, respectively.

The aeromagnetic data are from the 1105 Aerogeophysical Project: São José dos CamposResende carried out by Microsurvey Aerogeophysics and Scientific Consulting LTDA (CPRM/DNPM, 2013). This survey covered an area of $47,321 \mathrm{~km}^{2}$ covering the states of Minas Gerais, São Paulo and Rio de Janeiro. The N-S flight and E-W control lines are spaced $500 \mathrm{~m}$ and $10,000 \mathrm{~m}$, respectively. The average terrain clearance is $100 \mathrm{~m}$ over the ground. The average acquisition speed was of $265 \mathrm{~km} / \mathrm{h}$, providing a measurement every $7.4 \mathrm{~m}$. The preprocessing was made by Microsurvey Aerogeophysics and Scientific Consulting LTDA. The magnetic inclination and declination were $37.3^{\circ}$ and $-21.6^{\circ}$, respectively, possibly in the center of the area, away from the marine study area.

\section{PHYSICAL PRINCIPLE (VOXI)}

The processing of magnetic data was performed by Oasis Montaj® (Geosoft, 2015).

Inversion programs generally apply scalar susceptibility inversion, which is based on the idea that the magnetic domains align parallel to the geomagnetic field; however, this is not always the case (Barbosa \& Pereira, 2013). The formulation of the MVI method developed by Ellis et al. (2012) was fundamental to our model software choice because it allowed the representation of magnetic properties of rocks without requiring prior knowledge about the source and magnetization direction. The technique considers induced and remanent magnetization, demagnetization and anisotropy of magnetic materials to calculate the amplitude and direction of source magnetic domains (Barbosa \& Pereira, 2013).

Consider a magnetic source with a certain volume $V$ with magnetization $\boldsymbol{M}(\boldsymbol{r})$. From the magnetostatic theory, the density of the magnetic flux $\boldsymbol{B}$ at $\boldsymbol{r}_{\boldsymbol{j}}$ is given by (Ellis et al., 2012): 


$$
B\left(r_{j}\right)=\nabla \int_{v} M(r) \nabla \frac{1}{\left|r-r_{j}\right|} d r^{3}
$$

Discretizing volume $V$ in $v_{k}$ volumes with a constant magnetization $m_{k}$ in each volume, we can write Eq. (1) as:

$$
B_{\beta}\left(r_{j}\right)=\sum_{k, \alpha}^{N, 3} m_{k, \alpha} \int_{v_{k}} \partial_{\alpha} \partial_{\beta} \frac{1}{\left|r-r_{j}\right|} d r^{3}
$$

where $(\alpha, \beta)$ indexes are the spatial coordinates of the vectors. Eq. (2) represents the forward model for a given set of causative sources (Ellis et al., 2012). Therefore, we can represent the magnetic field $B$ as follows:

$$
B=G m
$$

where $G$ is the sensitivity matrix. Eq. (3) represents the inverse problem for a given $B$. The solution of Eq. (3) results in $M$, the magnetization vector.

The MVI is based on the combination of two scalar components of the magnetization vector - known as the Amplitude component - generated in inversion. One component is the Projected (parallel to the Earth field) and the other is the Perpendicular (perpendicular to the Earth field). They help to analyze the importance of the inductor field and determine how to proceed in the iteration of the model (Fig. 3) (Smith, 2018). At the end of the process we obtain a 3D model that represents the complex subsurface geology more realistically.

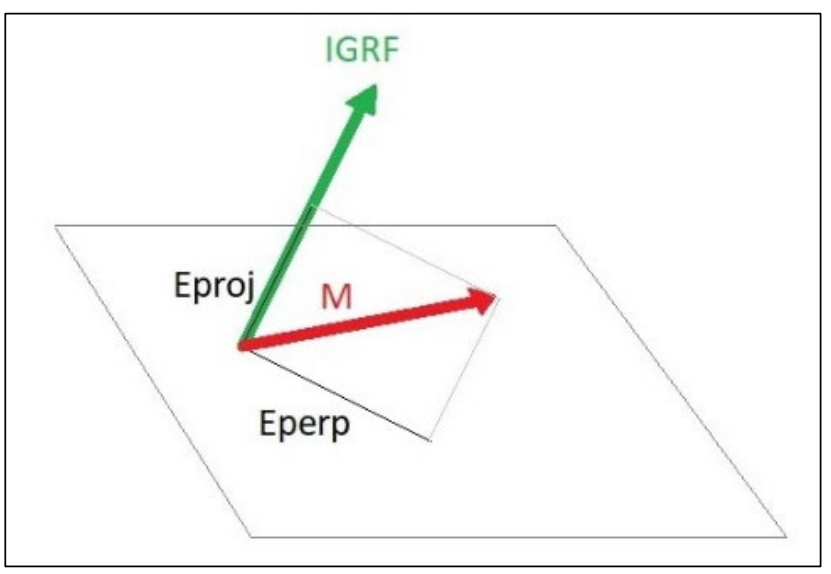

Figure 3 - The magnetization vector $(M)$, known as the Amplitude component, can be represented by two scalar components: Projected component (Eproj) and Perpendicular component (Eperp), based on Smith (2018).

\section{RESULTS}

\section{Marine Magnetic Maps}

Diurnal correction (Fig. 4) was applied to magnetic marine data. In Figure 4, we have the profiles of the diurnal variation of the magnetic field measured by the base magnetometer. Note that on October 6th, the diurnal variation presents small amplitude peaks during the daylight, superimposed in a large wavelength when compared to October 7th (Fig. 4).

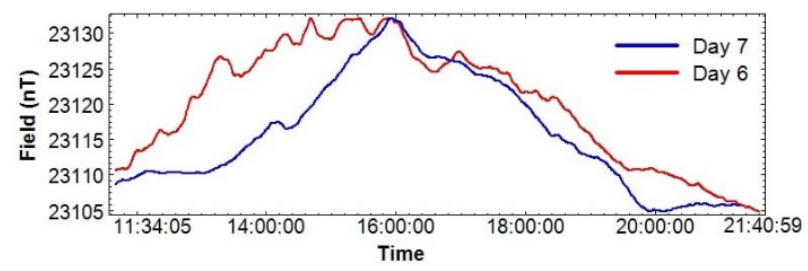

Figure 4 - Diurnal variation profiles for October 6th and 7th.

After the diumal correction, we removed the International Geomagnetic Reference Field (IGRF). The total field magnetic anomaly (TFMA) can be seen in Figure $5 \mathrm{~A}$. The map was done using Minimum Curvature interpolation with an $X$ and $Y$ spacing of grid lines of $70 \mathrm{~m}$ which corresponds to $1 / 5$ of the average spacing of acquisition lines of $350 \mathrm{~m}$. The grid spacing is a compromise between the data localization (Fig. 2) in the area and the requirement for not creating false anomalies. For randomly distributed data, the Minimum Curvature Method is the most appropriate (Erdi-Krausz et al., 2003).

The most important feature in the TFMA is the NESW trend in the magnetic anomalies (Fig. 5A). Besides, we notice some linear features with reverse polarity at PMR close to 538,500 UTMX, 7,431,000 UTMY coordinate (Fig. 5A). We applied the upward continuation filter of $1500 \mathrm{~m}$ to TFMA to observe regional trends (Fig. $5 B$ ). Notice in Figure 5B that the field amplitude increases in the SE direction. The $1500 \mathrm{~m}$ level is the minimum altitude for which the influence of short-wavelength anomalies was no longer observed after upward continuation tests, each $200 \mathrm{~m}$, not included here.

The residual magnetic field map (Fig. 5C) was obtained by the difference between the TFMA (Fig. 5A) and the regional magnetic field (Fig. 5B). The residual map highlights short-wavelength magnetic anomalies located in the most superficial portion of the crust. Comparing Figures $5 \mathrm{~A}$ and $5 \mathrm{C}$ we notice that the residual map enhances the linear trend, especially in the middle of the area, better defining the positive and negative parts of some anomalies. There are also anomalies in the south of the inner portion of MR (Fig. $5 \mathrm{C}$ ) that are not visible in Figure 5A. 

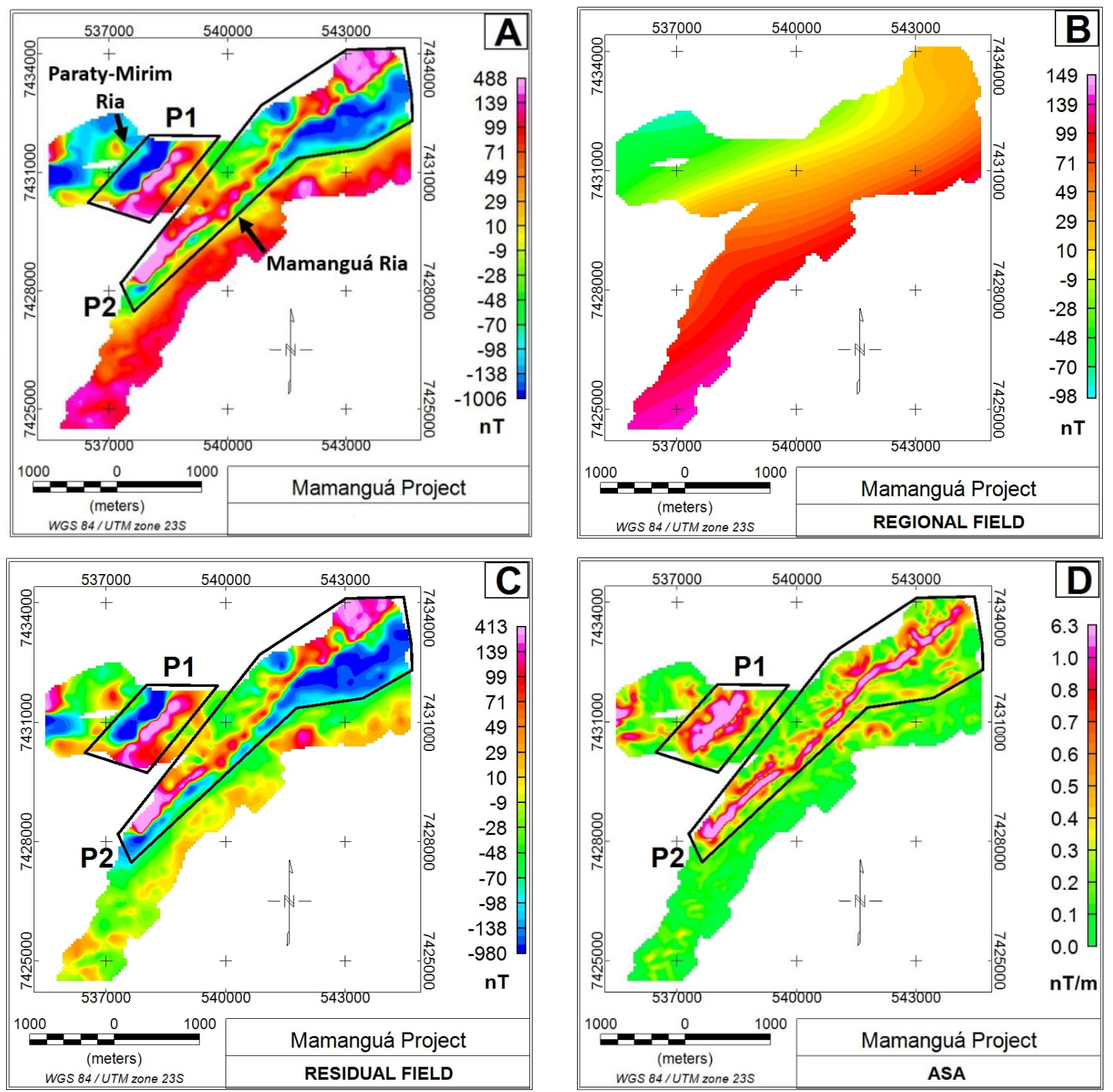

Figure 5 - TFMA (A), regional field (B), residual field (C), ASA (D) maps for marine magnetic data. In (A), (C) and (D) the target areas are highlighted: polygon P1 refers to a magnetic anomaly with reverse polarity, while polygon P2 refers to a normal polarity anomaly. The ASA (D) marks the horizontal location of the causative sources and outlines the orientation of the anomalies.

The 2D Analytical Signal Amplitude (ASA) was applied to the residual field (Fig. 5C) to highlight and detail the edges of the anomalous sources. The 2D ASA is expressed as the module horizontal gradients ( $X$ and Y) of the magnetic field (Nabighian, 1972; Blakely,1996). This filter tends to position the maximum peaks on the edges of the bodies and the minimum values in the center of the font. According to Blakely (1996), the steepest gradient will position exactly on the body edge if the edge is vertical and there is no influence from other sources.
Figure 5D shows that ASA enhances the continuity of the linear features and the narrowing of the edges of anomalous bodies mainly in the central and outer portions of the MR. This last effect is probably related to lateral magnetization concerning the surrounding bodies. These gradient zones between positive and negative anomalies suggest possible faults (Yan et al., 2018).

The anomalies with different polarities are marked by polygons $\mathrm{P} 1$ and $\mathrm{P} 2$ in Figures $5 \mathrm{~A}$ and $5 \mathrm{C}$. The anomaly of polygon $\mathrm{P} 1$ presents reverse polarity, typical of a remanent magnetization, and may be associated with a 
geological contact/2D body approximately $1.5 \mathrm{~km}$ long in the PMR. Polygon P2 comprises a normal polarity anomaly associated with induced and remanent magnetizations at the same direction, and it can be correlated to fault/intrusive feature/geological contact approximately $9 \mathrm{~km}$ long in the MR. These observations make it possible to make inferences about some conditions imposed upon the rocks that may influence or be responsible for the polarity of magnetic anomalies: (1) the age of emplacement; (2) magnetite grain size; (3) regional metamorphic events younger than the structures; (4) presence of titanomagnetite; (5) extreme oxidation; (6) regional hydrothermal alteration (Grant, 1985; Clark, 1997).

\section{Aeromagnetic Maps}

Considering the small size of the marine survey area, especially for the reverse anomaly of polygon P1 (Fig. $5 \mathrm{C}$ ), we opt to use the aeromagnetic survey to observe the trend and anomalies in a larger area. The airborne data were interpolated with Minimum Curvature Method with a cell size of $125 \mathrm{~m}$, i.e. $1 / 4$ of the flight line spacing (Reeves, 2005) of $500 \mathrm{~m}$. The TFMA shows reverse and normal NE-SW magnetic lineaments in the central-south portion, an expressive WNW lineament in the north, and long-wavelength anomalies in the southeast and north portion of the map (Fig. 6A). Note that the positive component of the northern portion of the P2 lineament (marked by an ellipse in Fig. 6A) is part of an anomaly located near the edge of the marine acquisition area (Fig. 5C). This anomaly, in the marine data, shows up with high amplitude and large wavelength compared with the other linear anomalies observed in Figure $5 \mathrm{C}$.

The 2D ASA (Fig. 6B) applied to TFMA (Fig. 6A) marks possible $3 \mathrm{D}$ bodies of expressive dimension located in the southeast portion of the map, at Santos Basin, and arranged along the NE-SW regional lineaments in the northern portion. These long-wavelength anomalies (Figs. 6A and 6B) may represent plutons associated with the magmatism of marine volcanic islands. The observed regional lineaments represent possible fault zones in the basement below the sedimentary column; geological contacts; and/or intrusive features comprising the offshore and onshore portions.

\section{Magnetization Vector Inversion Marine Magnetic Data}

To study the variable magnetization direction on the marine area we used the MVI algorithm applied at the residual magnetic field (Fig. $5 \mathrm{C}$ ). The objective here was to define the shallow sources. Schmick (2018) informs that the ideal cell size is not a function of line spacing, but a function of source-sensor spacing. As the sources do not emerge and there is no information on the depth of the top of the body, the choice of the appropriate cell size was based on test results. We choose the one that better delineated the continuity of the linear features and avoided the formation of mathematical artifacts. So, the best cell size for this survey is $X=150 \mathrm{~m}, Y=150 \mathrm{~m}, Z=100 \mathrm{~m}$ and it was assumed that the target body varied in size and depth. As the area has a uniform response, the absolute error of $8 \%$ provides a mismatch with a regular distribution. This type of error tends to better adjust major anomalies (Schmick, 2018).

To refine the model, we modified some constraints on the algorithm run: the Iterative Weighting Inversion (IRI) Focus and the adjustment of EW/NS/Nertical Gradient Weighting. These parameters do not necessarily depend on external geological information. The IRI Focus factor was changed from 2 to 3 which produces a more compact and focused susceptibility distribution (Fig. 7A). The changes highlighted the distribution of positive and negative susceptibility of the model which indicates the presence of reverse magnetization in the area. This IRI Focus is more geologically reasonable and useful than the smoother unconstrained models. 

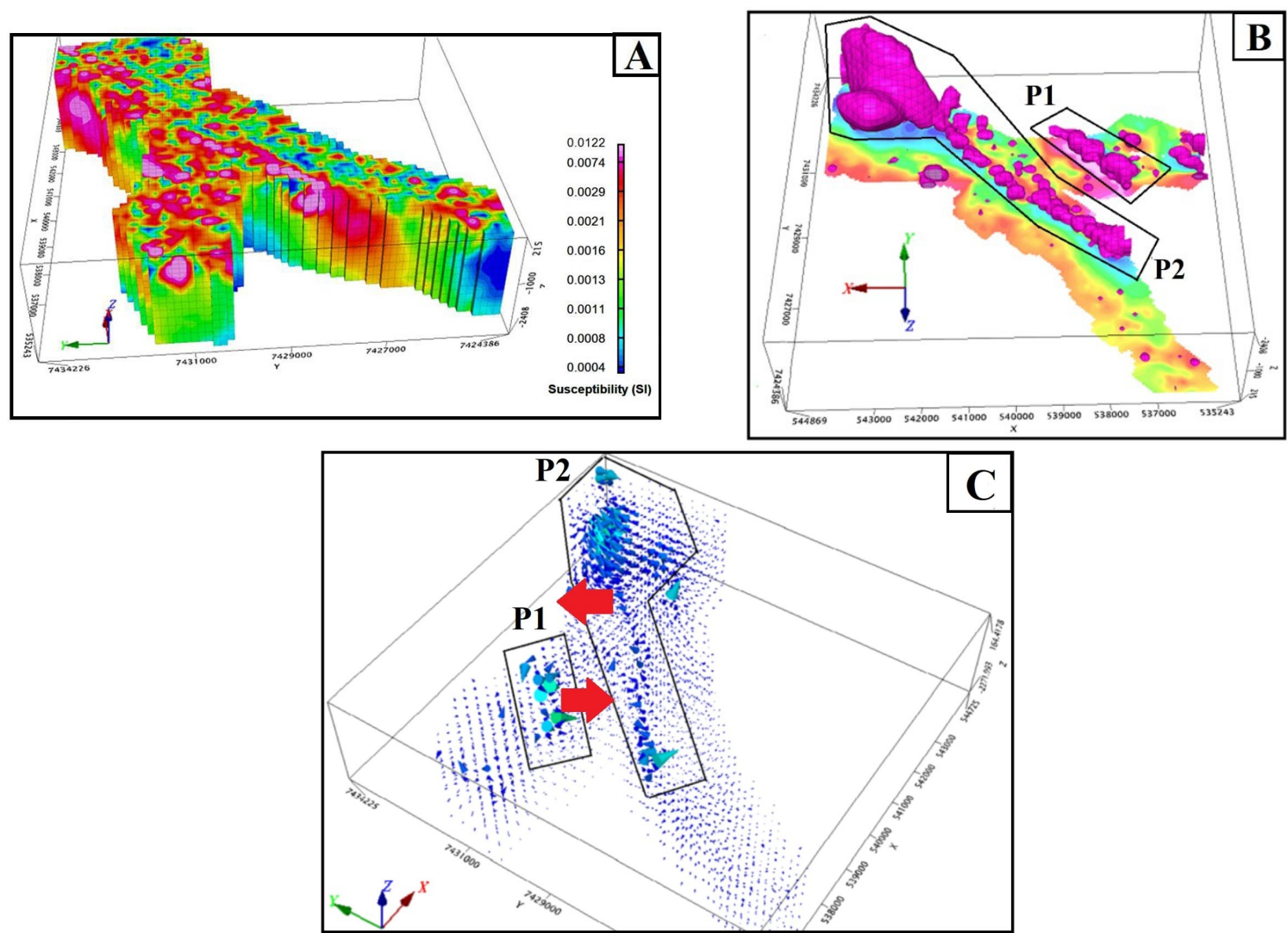

Figure 7 - VOXI MVI inversion results for the marine magnetic data: (A) MVI mesh, (B) Isosurface of $0.009 \mathrm{SI}$ and (C) direction and intensity of the magnetization vectors. The amplitude of the magnetization vectors varies between 0.04 and $0.33 \mathrm{~A} / \mathrm{m}$. In (C) the average directions (red arrow) of the magnetization vectors for each polygon (P1 and P2) are shown. The axes are in meters. Note that the NE-SW lineaments are well signaled in $(B)$.

EW/NS/Vertical Gradient Weighting represents the confidence level of susceptibility along with the features of interest. This is done by choosing values ranging from 0 to 1, where 0 indicates less smoothness and 1 more smoothness along the specified direction in the transition from the grid's cell to cell. The NE-SW linear features (Figs. 5A and $5 \mathrm{C}$ ) in the study area are associated with physical discontinuities between different lithological units (Fig. 1). The directional weighting values that resulted in the most satisfactory voxel model consistent with the features highlighted in the ASA map (Fig. 5D) were: EW and NS directions equal to 0.7 and 0.5 for the vertical direction. The RMS (Root Mean Square) misfit between the observed residual (Fig. 5C) and predicted field from the 3D magnetic inversion is $0.08 \mathrm{nT}$, indicating a satisfactory fit to the marine magnetic data.

Figure 7 shows the VOXI MVI inversion results for marine data. The MVI mesh indicates that the linear features of interest represent geological structures with mean susceptibility values close to $0.01 \mathrm{SI}$ (Fig. 7A). The representative isosurface model of $0.009 \mathrm{SI}$ (Fig. 7B) points to basaltic $(0.0002-0.175 \mathrm{SI})$, diabase $(0.001-0.160 \mathrm{SI})$ and/or diorite $(0.0006-0.120 \mathrm{SI})$ bodies (Telford et al., 1990). Observing the vertical position of the modeled bodies, it is likely that the body associated with polygon P2 has little sedimentary thickness (Fig. 7A). The vector model shows that the mean direction of the total magnetization vectors is different for the two areas (polygons P1 and P2), reinforcing the inference initially made about the presence of normal and inverse magnetization.

\section{Airborne Magnetic Data}

We used the TFMA (Fig. 6A) as input when applying MVI to airborne data since our focus is on deeper structures such as the basement. The cell size is set as $X=300 \mathrm{~m}$, $Y=300 \mathrm{~m}, \mathrm{Z}=200 \mathrm{~m}$. The acquisition area $\left(47,321 \mathrm{~km}^{2}\right)$ of this data has many anomalies with different amplitudes 
and size. We worked with the relative error to highlight the area characteristics. The relative error tends to attribute minor errors to minor anomalies, forcing inversion to attribute major errors to major anomalies (Schmick, 2018). A larger error implies a larger difference between observations and model prediction. We set a relative error of $3 \%$ of each measurement. The only modified constraint was the IRI Focus, change to 3 , to show positive and negative physical properties of the model. The RMS misfit between the observed TFMA (Fig. 6A) and predicted field from the 3D magnetic inversion is $2.24 \mathrm{nT}$, indicating a reasonable fit to the aeromagnetic data.

The results of the VOXI MVI inversion for aeromagnetic data are in Figure 8. The MVI mesh highlights the swarm of magnetic lineaments in the entire area (Fig. 8A). A representative isosurface model of 0.02 $\mathrm{SI}$ is shown to illustrate the regional features (Fig. 8B). Note that the anomalies are well represented by anomalous sources (Figs. 8A and 8B), but the variations in the direction vectors of total magnetization seem less significant (Fig. 8C) compared with results from marine data (Fig. $7 \mathrm{C}$ ), possibly due to cell size used here. The inversion results showed the presence of inverse remanent magnetization (Figs. $7 \mathrm{C}$ and $8 \mathrm{C}$ ) for polygon $\mathrm{P1}$ and normal magnetization for polygon $\mathrm{P} 2$. The results also showed a significant contrast of apparent magnetic susceptibility between the anomalies of interest (polygons $\mathrm{P} 1$ and $\mathrm{P} 2$ ) and the anomalies in the surrounding area (Figs. 8A and 8B).

\section{DISCUSSION}

We suggest a correlation of the observed magnetic lineaments with the swarms of tholeitic basaltic dykes of Serra do Mar and Resende - llha Grande (RJ). The magnetic lineaments have a preferential direction of $\mathrm{N} 40^{\circ}$ $50^{\circ} \mathrm{E}$ that is in accord with the observations for those swarms. The Serra do Mar Swarm is characterized by subvertical dykes oriented to $\mathrm{N} 40^{\circ}-50^{\circ} \mathrm{E}$ (Almeida, 1986), $\mathrm{N} 30^{\circ}-40^{\circ} \mathrm{E}$ (Almeida et al., 2013) and mostly $\mathrm{N} 50^{\circ}-65^{\circ} \mathrm{E}$ (Marques \& Ernesto, 2004). The Resende-llha Grande Swarm has dykes with three distinct directions: NNW (inner portion), NS-NNE (central portion) and NE (coastal region) that intrude the Precambrian gneiss basement (Guedes et al., 2016).

The modeled magnetic susceptibility values vary between 0.0001 and $1.4 \mathrm{SI}$ (Fig. 8A) for the aeromagnetic data and 0.0004 to $0.01 \mathrm{SI}$ (Fig. 7A) for marine data. This wide range of values may represent the gneissic ( 0.0001 $0.025 \mathrm{SI}$ ) and granitic (0 - $0.05 \mathrm{SI}$ ) (Telford et al., 1990) rocks of the units Rio Negro, Parati Granite and ParatiMirim Granite (Fig. 1) and may also be associated with intrusive features as gabbro (0.001 - $0.09 \mathrm{SI}$ ), amphibolite (0.7 SI), basalt, diabase, diorite and andesite (0.16 SI). According to Almeida (1986), the Serra do Mar dykes are mainly composed of gabbro, diorite, tholeitic diabase and andesite. Marques \& Ernesto (2004) claim that circa 85\% of the outcrops are of the high Ti type (TiO2 > 3\%). The observed magnetic signal amplitude and inversion results for the magnetic susceptibility correlate with the geology and mineralogy for the area.

Another interesting aspect of the dykes swarms is their age. The Serra do Mar Swarm is associated with the Meso-Cenozoic tholeiitic-alkaline magmatism in southsoutheast Brazil, resulting from the separation of supercontinent Gondwana (130 - $120 \mathrm{Ma}$; Guedes et al., 2016) along the South Atlantic Ocean. The onshore representations of those dykes have been dated for different authors resulting in the interval of 119 to $140 \mathrm{Ma}$ (133 - 131 Ma: Thiede \& Vasconcelos (2010); 132 - 119 Ma: Marques \& Ernesto (2004); 140 - $130 \mathrm{Ma}$ : Peate et al. (1992) and Turner et al. (1994)). The Resende-llha Grande tholeiitic dykes (156 - $144 \mathrm{Ma}$ ) are associated with extensive processes and magmatic episodes that occurred between Karoo (181 - $178 \mathrm{Ma}$ ) and ParanáEtendeka (134 - $133 \mathrm{Ma}$ ) Magmatic Provinces (Guedes et al., 2016). The Resende-llha Grande Swarm is older than the Paraná-Etendeka Magmatic Province and the Serra do Mar Swarm. In this way, the studied offshore and onshore structural lineaments may be associated with previous volcanic activities (Resende-llha Grande Swarm) and/or after and during (Serra do Mar Swarm) the rupture of Gondwana. During the time interval of the two dykes swarms events the geomagnetic field alternated polarity (Walker et al., 2013), so both swarms may have formed in the area. 

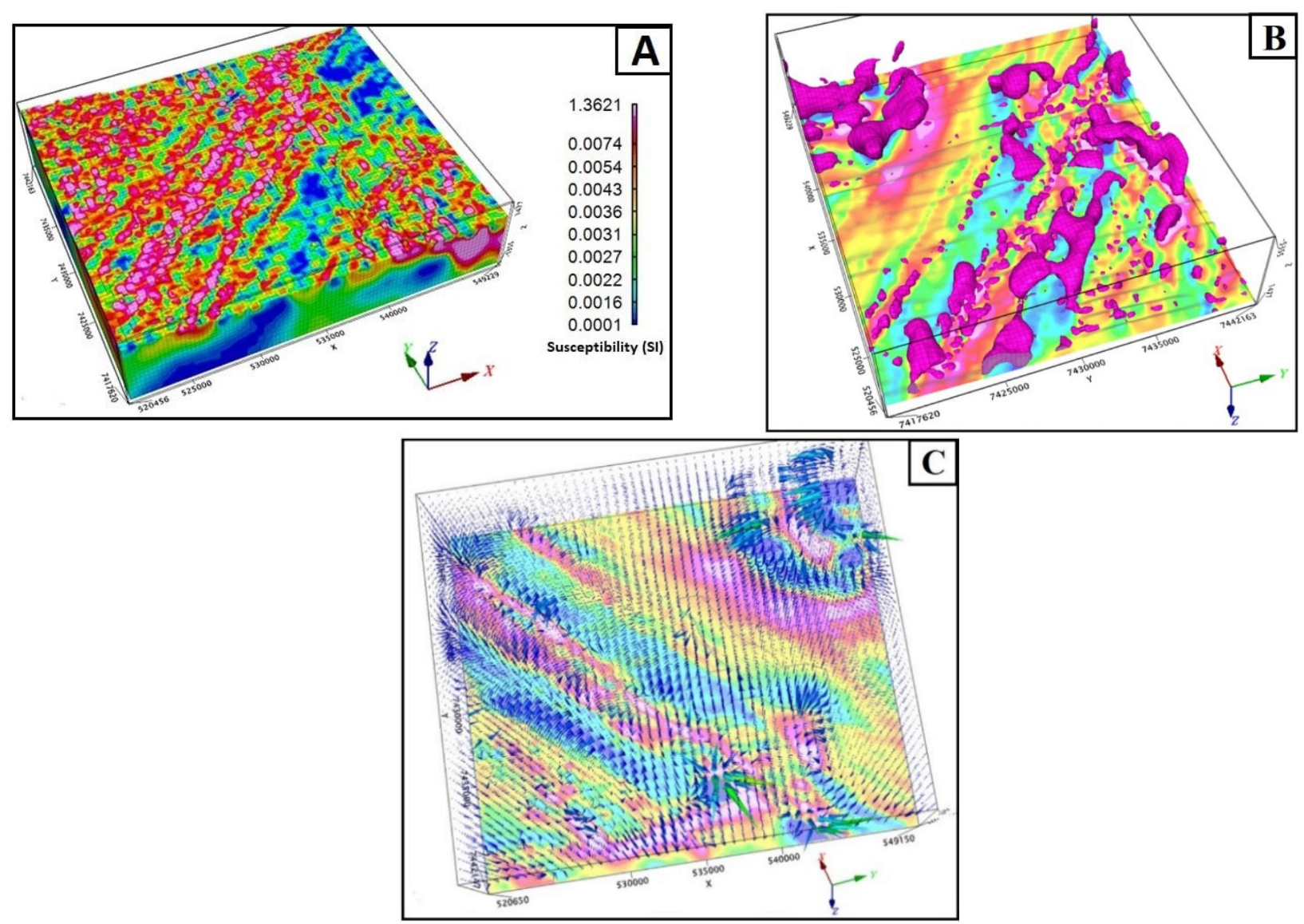

Figure 8 - VOXI MVI inversion results for the aeromagnetic data: (A) MVI, (B) Isosurface of $0.02 \mathrm{SI}$ and (C) direction and intensity of the magnetization vectors. The amplitude of the magnetization vectors varies between 0.1 and $0.6 \mathrm{~A} / \mathrm{m}$. The axes are in meters. Note that the NE-SW lineaments are well signaled in (A).

\section{CONCLUSION}

The main features identified through the integration of marine and airborne data are the magnetic lineaments with a $\mathrm{N} 40^{\circ}-50^{\circ} \mathrm{E}$ trend, covering the gneissic, granitic and migmatitic terrains of the area surrounding the rias. These lineaments can be associated with extensive fault zones, intrusive features and/or geological contacts. In our interpretation, they were associated with the basic tholeiitic dykes swarms present in the area and with the geological contacts of Rio Negro, Parati-Mirim Granite and Parati Granite units in the basement. Besides, it has been shown that there is a contrast of susceptibility between marine sources and regional structures. In the marine portion, two zones with distinct magnetic polarity were highlighted. The main linear feature of PMR can be associated with tabular source/geological contact with remanent magnetization, approximately $1.5 \mathrm{~km}$ long. In RM, the linear structure can be correlated to intrusive feature/fault plan/geological contact with normal magnetization, approximately $9 \mathrm{~km}$ long.

For marine and airborne data, the MVI susceptibility models are aligned with the interpretation of the ASA.
The MVI's qualitative interpretation showed coherence with local and regional geology and highlighted areas with strong remanent magnetization, such as the anomalous source in the PMR. In the case of the airborne data, the MVI results did not show good resolution for the total magnetization vector voxel, possibly due to the cell size used for the model.

We also concluded that the magnetic lineaments probably are related to Resende-llha Grande and Serra do Mar dykes swarms, that have different ages. Those ages can be set at time intervals for normal and reverse polarities of the Earth's magnetic field.

\section{ACKNOWLEDGMENTS}

JA thanks FAPESP process n. 2019/12200-0 for the scholarship, to FAPESP process n. 16/24946-9 and $18 / 17061-6$, to Roberto Zanon, for the technical collaboration and to the CPRM, DNPM and IO-USP institutions for making geoscientific data available. The authors are also grateful for the reviewers' comments that improved the manuscript. 


\section{REFERENCES}

ALMEIDA FFM. 1986. Distribuição regional e relações tectônicas do magmatismo Pós-Paleozóico no Brasil. Revista Brasileira de Geociências, 16(4): 325-349.

ALMEIDA FFM \& CARNEIRO CDR. 1998. Origem e evolução da Serra do Mar. Revista Brasileira de Geociências, 28(2): 135-150.

ALMEIDA J, DIOS F, MOHRIAK WU, VALERIANO CDM, HEILBRON M, EIRADO LG \& TOMAZZOLI E. 2013. Pre-rift tectonic scenario of the Eo-Cretaceous Gondwana break-up along SE Brazil - SW Africa: insights from tholeiitic mafic dyke swarms. Geological Society, London, Special Publications, 369(1): 11-40.

BARBOSA RD \& PEREIRA JG. 2013. Inversão 3D de dados magnéticos na região de Mara Rosa - Goiás, Brasil, utilizando Geosoft VOXI. In: International Congress of the Brazilian Geophysical Society. 13., 2013, Rio de Janeiro. Proceedings... Rio de Janeiro, RJ, Brazil: SBGf, 2013. CD-ROM.

BENITES M, ALVES DP, MALY MDLS \& JOVANE L. 2015. Shallow gas occurrence in a Brazilian ria (Saco do Mamanguá, Rio de Janeiro) inferred from highresolution seismic data. Continental Shelf Research, 108: 89-96.

BLAKELY RJ. 1996. Potential theory in gravity and magnetic applications. 2nd ed., Cambridge: Cambridge University Press. 461 pp.

BRANDINI FP, SAYEG L, RUSKE G, CAMPOS G, CHUQUI M \& JOVANE L. 2019. Carbon flow for plankton metabolism of Saco do Mamanguá Ria, Bay of Ilha Grande, a subtropical coastal environment in the South Brazil bight. Frontiers in Marine Science, 6: 584.

CASTAING P \& GUILCHER A. 1995. Geomorphology and sedimentology of rias. In: PERILLO G (Ed.). Developments in Sedimentology. Amsterdam: Elsevier. v 53, chapter 4. p. 69-111.

CLARK DA. 1997. Magnetic petrophysics and magnetic petrology: aids to geological interpretation of magnetic surveys. AGSO Journal of Australian Geology and Geophysics, 17: 83-104.

CPRM/DNPM. 2013. Relatório final do levantamento e processamento dos dados magnetométricos e gamaespectrométricos. São José dos CamposResende, Brazil. 297 pp.
DANTAS ME. 2000. Geomorfologia do estado do Rio de Janeiro: texto explicativo do mapa geomorfológico do estado do Rio de Janeiro na escala 1:50.000. CPRM/DRM, Brazil. 1-75 pp.

ELLIS RG, WET BD \& MACLEOD IN. 2012. Inversion of magnetic data for remanent and induced sources. In: ASEG Conference \& Exhibition. 22., Extended Abstracts. Brisbane, Australia. 2012 (1): 1-4.

ERDI-KRAUSZ G, MATOLIN M, MINTY B, NICOLET JP, REFORD WS \& SCHETSELAAR EM. 2003. Guidelines for radioelement mapping using gamma ray spectrometry data: also as open access e-book. International Atomic Energy Agency (IAEA), Vienna, Austria. vol. 1363, 179 pp.

GEOSOFT INC. 2015. OASIS Montaj. version 8.4 User Guide. Geosoft Incorporated, Toronto, Canada.

GRANT FS. 1985. Aeromagnetics, geology and ore environments, I. Magnetite in igneous, sedimentary and metamorphic rocks: An overview. Geoexploration, 23(3): 303-333.

GUEDES E, HEILBRON M, VALERIANO CDM, ALMEIDA JCHD \& SZATMARI P. 2016. Evidence of Gondwana early rifting process recorded by ResendeIlha Grande Dike Swarm, southern Rio de Janeiro, Brazil. Journal of South American Earth Sciences, 67: $11-24$.

MALY MDLS. 2017. Avaliação da técnica da eletrorresistividade no mapeamento de sedimentos rasos associados à ocorrência de gás no Saco do Mamanguá e na Enseada de Paraty-Mirim. Master Dissertation on Oceanography - Programa de PósGraduação em Oceanografia Geológica, Instituto Oceanográfico, Universidade de São Paulo, SP, Brazil, 2017. 94 pp.

MARQUES LS \& ERNESTO M. 2004. O magmatismo toleítico da Bacia do Paraná. In: MANTESSO NETO V, BARTORELLI A \& CARNEIRO CR (Org.). Geologia do continente Sul-Americano: evolução da obra de Fernando Marques de Almeida. São Paulo, Brazil: Beca. cap. XV, p. 245-263.

MELO JA, MARANGONI YR \& JOVANE L. 2019. Análise preliminar dos dados magnéticos do Saco do Mamanguá e da Enseada de Paraty-Mirim, Rio de Janeiro Brasil. In: International Congress of the 
Brazilian Geophysical Society. 16., 2019, Rio de Janeiro. Proceedings... Rio de Janeiro, Brazil: SBGf, 2019. CD-ROM.

NABIGHIAN MN. 1972. The analytic signal of twodimensional magnetic bodies with polygonal crosssection: its properties and use for automated anomaly interpretation. Geophysics, 37(3): 507-517.

PEATE DW, HAWKESWORTH CJ \& MANTOVANI MSM. 1992. Chemical stratigraphy of the Paraná lavas (South America): classification of magma types and their spatial distribution. Bulletin of Volcanology, 55(12): 119-139.

PLETS R, DIX J \& BATES R. 2013. Marine geophysics data acquisition, processing and interpretation. English Heritage. 48 pp.

REEVES C. 2005. Aeromagnetic Surveys: Principles, Practice \& Interpretation. Geosoft. 155 pp.

RODELLI D, JOVANE L, GIORGIONI M, REGO ES, CORNAGGIA F, BENITES M, CEDRAZ P, BERBEL GBB, BRAGA ES, USTRA A, ABREU $F$ \& ROBERTS AP. 2019. Diagenetic fate of biogenic soft and hard magnetite in chemically stratified sedimentary environments of Mamanguá Ría, Brazil. Journal of Geophysical Research: Solid Earth, 124(3): 2313-2330.

SCHMICK. 2018. Top 5 Inversion Best Practices: Episode 1 - Auxiliary Parameters. Geosoft Videos.

SILVA LCD \& CUNHA HCDS. 2001. Geologia do estado do Rio de Janeiro: texto explicativo do mapa geológico do estado do Rio de Janeiro. Brasília, DF, Brazil: CPRM, 1-12.

SILVESTRE PG. 2016. Paisagem e turismo: um estudo sobre a região de Saco do Mamanguá - RJ como uma oportunidade para o turismo. Monograph on Geography - Programa de Graduação em Geografia, Instituto de
Ciências Humanas. Universidade Federal de Juiz de Fora, MG, Brazil, 2016. 70 pp.

SMITH. 2018. Top 5 Inversion Best Practices: Episode 4 - Interpreting MVI Components. Geosoft Videos.

SOARES ACP, NOCE CM, ALKMIM FFD, SILVA LCD, BABINSKI M, CORDANI UG \& CASTAÑEDA C. 2007. Orógeno Araçuaí: síntese do conhecimento 30 anos após Almeida 1977. Geonomos, 15(1): 1-16.

SUGUIO K \& MARTIN L. 1978. Quaternary marine formations of the state of São Paulo and southern Rio de Janeiro. In: International Symposium on Coastal Evolution in the Quaternary. 1., 1978, São Paulo. Proceedings... São Paulo, SP, Brazil: Special Publication, 1978, 1-55 pp.

TELFORD WM, GELDART LP \& SHERRIFF RE. 1990. Applied Geophysics. 2nd ed., Cambridge: Cambridge University Press, 760 pp.

THIEDE DS \& VASCONCELOS PM. 2010. Paraná flood basalts: rapid extrusion hypothesis confirmed by new 40Ar/39Ar results. Geology, 38(8): 747-750.

TURNER S, REGELOUS $M$, KELLEY $S$, HAWKESWORTH C \& MANTOVANI M. 1994. Magmatism and continental break-up in the South Atlantic: high precision ${ }^{40} \mathrm{Ar} / 39 \mathrm{Ar}$ geochronology. Earth and Planetary Science Letters, 121(3-4): 333-348.

WALKER JD, GEISSMAN JW, BOWRING SA \& BABCOCK LE. 2013. The Geological Society of America Geologic Time Scale. GSA Bulletin, 125(3-4): 259-272.

YAN J, WANG Z, WANG J \& SONG J. 2018. Using marine magnetic survey data to identify a gold orecontrolling fault: a case study in Sanshandao fault, eastern China. Journal of Geophysics and Engineering, 15(3): 729-738. 